\title{
Patient safety and nursing: interface with stress and Burnout Syndrome
}

\author{
Segurança do paciente e enfermagem: interface com estresse e Síndrome de Burnout \\ Seguridad del paciente y enfermería: interfaz con estrés y Síndrome de Burnout
}

\section{Cláudia Cristiane Filgueira Martins Rodrigues',"I, Viviane Euzébia Pereira Santos', Paulo Sousall}

'Universidade Federal do Rio Grande do Norte, Postgraduate Program in Nursing. Natal, Rio Grande do Norte, Brazil. "Universidade Nova de Lisboa, National School of Public Health, Postgraduate Program in Public Health. Lisboa, Portugal.

\section{How to cite this article:}

Rodrigues CCFM, Santos VEP, Sousa P. Patient safety and nursing: interface with stress and Burnout Syndrome.

Rev Bras Enferm [Internet]. 2017;70(5):1083-8. [Thematic Edition "Good practices and fundamentals of Nursing work in the construction of a democratic society"] DOI: http://dx.doi.org/10.1590/0034-7167-2016-0194

\author{
Submission: 05-19-2016 Approval:04-02-2017
}

\begin{abstract}
Objective: To analyze studies on stress, Burnout Syndrome, and patient safety in the scope of nursing care in the hospital environment. Method: This was an integrative literature review. Data collection was performed in February 2016 in the following databases: Medical Literature Analysis and Retrieval System Online - PubMed/MEDLINE, Latin American and Caribbean Literature in Health Sciences - LILACS. Results: Ten scientific productions were selected, which listed that factors contributing to stress and Burnout Syndrome of nursing professionals are the work environment as a source of stress, and excessive workload as a source of failures. Conclusion: The analysis found that the stress and Burnout Syndrome experienced by these professionals lead to greater vulnerability and development of unsafe care, and factors such as lack of organizational support can contribute to prevent these failures.
\end{abstract}

Descriptors: Nursing; Patient Safety; Professional Stress; Burnout Syndrome; Professional Exhaustion.

\section{RESUMO}

Objetivo: Analisar estudos que versam sobre o estresse e Síndrome de Burnout, bem como a segurança do paciente no âmbito da assistência de enfermagem no ambiente hospitalar. Método: Tratou-se de uma revisão integrativa de literatura. O levantamento dos dados foi efetuado nas bases de dados Medical Literature Analysis and Retrieval System Online - PubMed / MEDLINE, Literatura Latino-Americana e do Caribe em Ciências da Saúde -LILACS em fevereiro de 2016. Resultados: Foram selecionadas10 produções científicas que apontaram que os fatores que contribuem para o estresse e a Síndrome de Burnout dos profissionais de enfermagem são o ambiente de trabalho como fonte de estresse e a carga de trabalho excessiva como geradora de falhas. Conclusão: A análise apontou que o estresse e a Síndrome de Burnout vivenciada por esses profissionais acarretam maior vulnerabilidade ao desenvolvimento de uma assistência insegura e que fatores como a falta de apoio organizacional podem contribuir para dirimir essas falhas.

Descritores: Enfermagem; Segurança do Paciente; Estresse Profissional; Síndrome de Burnout; Esgotamento Profissional.

\section{RESUMEN}

Objetivo: Analizar estudios que versan sobre el estrés y el Síndrome de Burnout, así como la seguridad del paciente en el ámbito de la asistencia de enfermería en el ambiente hospitalario. Método: Se trata de una revisión integrativa de la literatura. El levantamiento de los datos se efectuó en febrero de 2016 en las bases de datos del Medical Literature Analysis and Retrieval System Online PubMed / MEDLINE y Literatura Latinoamericana y del Caribe en Ciencias de la Salud -LILACS. Resultados: Se seleccionaron diez producciones científicas que apuntaron que los factores que contribuyen con el estrés y el Síndrome de Burnout de los profesionales de enfermería son el ambiente de trabajo como fuente de estrés y la carga de trabajo excesiva como generadora de fallas. Conclusión: El análisis apuntó que el estrés y el Síndrome de Burnout vivido por esos profesionales acarrean una mayor vulnerabilidad al desarrollo de una asistencia insegura y que factores como la falta de apoyo organizacional pueden contribuir a impedir esas fallas. Descriptores: Enfermería; Seguridad del Paciente; Estrés Profesional; Síndrome de Burnout; Agotamiento Profesional. 


\section{INTRODUCTION}

Patient safety has been a global trend in recent decades, which reflected on increasing research for quality improvement in health services and dissemination of good care practices ${ }^{(1)}$.

Thus, concern about safe care has become an international challenge and is a frequent theme in scientific studies. Several studies $^{(1-3)}$, searched for clarifications and definitions about the main causes of adverse events within health institutions, and the possibilities of barriers.

Somestudies ${ }^{(2-3)}$ show most of these failures are a result of the complexity of care developed,the association of growing technological advances and poor human resources development, and the lack of motivation of professionals providing the care.

Other aspects at the heart of these discussions are factors related to the work environment and their interaction with specific demands of the profession and health professionals' well-being. The work overload, inadequate staff sizing and unhealthy working conditions cause high mental and physical workload on professionals, and unsafe assistance as a consequence $^{(3-5)}$.

Studies indicate the excessive workload is a risk factor that stimulates the development of professional stress and Burnout Syndrome. Thus, it leads to workers' sickness in the work environmentand absenteeism as a direct consequence, which reduces the quantity of workers by served patients, reflects in poor organization of care and may lead to poor quality of care ${ }^{(4-8)}$.

An investigation conducted in 30 hospitals in the United States poses as an example. It was identified that nursing professionals of units with high workload are more likely to have Burnout Syndrome and work dissatisfaction, and evaluate the care of their units as unsafe and of poor quality ${ }^{(8)}$.

In Brazil, this occurrence is also frequent. Poor working conditions, limited resources, overcrowding, and long waiting time in emergency services of public hospitals cause a higher predisposition to incidents and failures in patient care ${ }^{(5)}$.

This intense work environment demands from workers a greater capacity ofadaptation to adversities of the workplace, and stress and the Burnout Syndrome result as consequence of this routine in the workplace.

Stress and Burnout Syndrome in nursing workers are associated with impairment of patient safety ${ }^{(9)}$. Moreover, these variables make professionals more vulnerable to the occurrence of incidents, and this way, they end up being positively related to care failures.

Therefore, it is important to improve studies about implications of stress and Burnout Syndrome on nursing care in the daily performance of their roles. This study will allow the reflection about how these factors may affect the occurrence of care failures.

Thus, the following research question is presented: what are the characteristics of studies on stress and patient safety? What is the influence of stress and Burnout Syndrome in nursing professionals and patient safety?

The aim of the present study was to answer such questions by analyzing studies on stress and Burnout Syndrome, and patient safety in nursing care within the hospital environment.

\section{METHOD}

This is an integrative review of the literature on stress and Burnout Syndrome of nursing professionals working in the hospital environment and their interface with patient safety.

This type of review is a methodology that summarizes knowledge and incorporates the applicability of findings of significant studies by identifying what is best on the topic of study hence, the foundation of any scientific study. In addition, it is a tool for practical applicability ${ }^{(10)}$.

The question and objective of the study were established based on the PCCmnemonic (P: Population; C: Concept; C: Context), in which P: Nursing professionals; C: Stress, Burnout Syndrome and Patient Safety; C: Hospital Environment. The study question designed after this definition was: what are the characteristics of studies on stress and patient safety? What is the influence of stress and Burnout Syndrome in nursing professionals and patient safety?

The search for scientific articles of primary source was performed in the following electronic databases: Medical Literature Analysis and Retrieval System Online - PubMed/ MEDLINE, Latin American and Caribbean Literature in Health Sciences - LILACS.

The selection of descriptors adopted the controlled terminology suggested by theMedical SubjectHeadings - MESH and theHealth Science Descriptors- DeCS, as follows: Segurança do paciente (Patient safety / Seguridad del Paciente); EstresseProfissional (Burnout, Professional/AgotamientoProfesional); Enfermagem (Nursing/ Enfermeria).

The search strategy followed the definition of each corresponding database, and were used the Boolean operators AND and OR. Figure 1 illustrates the combination of descriptors used in the PubMed/MEDLINE databases.

\begin{tabular}{l} 
("patient safety"[MeSH Terms] OR ("patient"[All Fields] AND "safety"[All Fields]) OR "patient \\
safety"[All Fields]) AND ("burnout, professional"[MeSH Terms] OR ("burnout"[All Fields] AND \\
"professional"[All Fields]) OR "professional burnout"[All Fields] OR ("burnout"[All Fields] AND \\
"professional"[All Fields]) OR "burnout, professional"[All Fields]) ("patient safety"[MeSH Terms] OR \\
("patient"[All Fields] AND "safety"[All Fields]) OR "patient safety"[All Fields]) AND \\
("nursing"[Subheading] OR "nursing"[All Fields] OR "nursing"[MeSH Terms] OR "nursing"[All Fields] \\
AND "loattrfree full text"[sb] \\
\hline
\end{tabular}

Figure1 - Search strategy model adopted in PubMed / MEDLINE databases

The search for articles was performed onFebruary $17^{\text {th }}$, 2016 according to the following inclusion criteria: scientific productions available in full texts on the themes of stress and Burnout Syndrome in nursing professionals and their interface with patient safety; scientific productions available as original articles; scientific productions available for free; scientific productions available in English, Portuguese and Spanish.

The following articles were excluded: thosenot addressing the relevant topic for the scope of the study; scientific productions available in the form of monographs, dissertations, theses, and others divergent from the original article; and duplicate studies.

The strategy of critical evaluation of results followed the following indicators: Type of study (research, evaluation of care practice, management evaluation); Place of study development 
(country); Year of publication; Journal; Method (type of study descriptive, exploratory, experimental, validation); Study design: Qualitative, Quantitative; Study environment (hospital, health units); Stress interface on patient safety; Limitations of the study; Conclusion of the study.

\section{RESULTS}

Fifty-eight articles that met the aforementioned inclusion criteria were found. After reading and analysis, 20 publications were dissonant with the theme, three were duplicates and 25 studies were not available in full, which resulted in ten articles for analysis in this review, or $17.2 \%$ of the initial universe.

Of the studied productions, nine $(90 \%)$ were original articles, and one $(10 \%)$ was an integrative review of the literature. The temporal dimension of publications ranged from 2007 to
2016, with the highest incidence offour (40\%) publications in 2012. There was a predominance of publications from countries in Europe (80\%) and in English (100\%). This fact reiterates and justifies the relevance of the present study, since there is a lack of research on this subject in Portuguese.

Quantitative studies were the most prevalent study design, andadopted in nine of the analyzed articles (90\%). Regarding the study environment, the hospital setting stood out as the most investigated place for the relationship between stress and patient safety, and this context was present in $100 \%$ of the analyzed studies.

Regarding the Patient Safety-Stress-Burnout Syndrome interface, discussions of the articles were focused on the following pillars: work environment as a source of stress, and excessive workload as a source of failure. Expressive results are shown in Chart 1 with the respective descriptions of the findings.

Chart 1 - Characterization of integrative review studies according to the objective, method, and stress-patient safety interface

\begin{tabular}{|c|c|c|}
\hline Objective & Method & Stress-patientsafety interface \\
\hline $\begin{array}{l}\text { To measure the relationships between } \\
\text { work environment and professional } \\
\text { exhaustion - exhaustion of nurses and } \\
\text { physicians. }\end{array}$ & Cross-sectional & $\begin{array}{l}\text { The chaotic work environment (poorly organized) was related to } \\
\text { professionals' stress, physical and mental exhaustion and with their intention } \\
\text { of leaving the position. In addition, emotional exhaustion, relationships of } \\
\text { time pressure to perform a given task, and lower levels of autonomy. }\end{array}$ \\
\hline $\begin{array}{l}\text { To explore the influence of the } \\
\text { characteristics of incidents andtheir } \\
\text { seriousness, and the reception of } \\
\text { emotional support related to nurses' work. }\end{array}$ & Longitudinal & $\begin{array}{l}\text { Fatigue and stress at work can interact to produce a lower quality of } \\
\text { patient care, thus increasing the frequency of clinical errors. }\end{array}$ \\
\hline $\begin{array}{l}\text { To identify the levels of factors in Irish } \\
\text { hospitals that have impact on nurses } \\
\text { and patient safety. }\end{array}$ & Cross-sectional & $\begin{array}{l}\text { Patient safety can be improved by the level of professional knowledge and } \\
\text { reduction of nurses' workload. In addition, increased qualification levels of } \\
\text { nursing professionals in hospitals, and the hospitals adjustment to staff sizing } \\
\text { are examples of how to improve patient safety. }\end{array}$ \\
\hline $\begin{array}{l}\text { To investigate the impact of environmental } \\
\text { factors on nurses' practice and work, and } \\
\text { the characteristics of Burnout at work by } \\
\text { reporting outcomes and quality of care. }\end{array}$ & Cross-sectional & $\begin{array}{l}\text { Health workers' feelings of exhaustion when dealing with unfavorable } \\
\text { environments result in low quality of care. }\end{array}$ \\
\hline $\begin{array}{l}\text { To examine if conditions in which } \\
\text { safety is organized affect the emotional } \\
\text { exhaustion and amount of work in } \\
\text { nursing units. }\end{array}$ & Cross-sectional & $\begin{array}{l}\text { The high rate of adverse events in the unit was negatively related to } \\
\text { the unit's organization and the emotional exhaustion of professionals } \\
\text { involved. }\end{array}$ \\
\hline $\begin{array}{l}\text { To determine if a good organization of } \\
\text { care can affect patient care in European } \\
\text { countries. }\end{array}$ & Cross-sectional & $\begin{array}{l}\text { Each additional patient per nurse increased the chances of reporting } \\
\text { care of poor or reasonable quality. The outcomes of high rates of } \\
\text { Burnout in nurses were related to intentions of leaving the position and } \\
\text { to job dissatisfaction. The effect of working conditions/environment was } \\
\text { generally stronger than the specific personal effect. }\end{array}$ \\
\hline $\begin{array}{l}\text { To give an overview of the wide range of } \\
\text { risks for nurses, patients and employers } \\
\text { whoare linked to shift work, long working } \\
\text { hours, and poor sleep quality from other } \\
\text { sources. }\end{array}$ & Cross-sectional & $\begin{array}{l}\text { Declines in leadership and neurocognitive performance were related to } \\
\text { higher rates of injuries, errors and fatigued workers. }\end{array}$ \\
\hline $\begin{array}{l}\text { To investigate the role of clinical } \\
\text { Burnout, demography and organizational } \\
\text { characteristics in predicting subjective and } \\
\text { objective indicators of patient safety. }\end{array}$ & Cross-sectional & $\begin{array}{l}\text { Patient safety evaluated by the physician was associated with exhaustion, } \\
\text { waking state and professional role. }\end{array}$ \\
\hline $\begin{array}{l}\text { To examine the effects of stress-related } \\
\text { work with regard to patient safety. }\end{array}$ & Cross-sectional & $\begin{array}{l}\text { Increased job demands, lack of professional self-control, and social } \\
\text { support were problems identified as influencing stress and patient safety. }\end{array}$ \\
\hline $\begin{array}{l}\text { To analyze the working conditions and } \\
\text { well-being of health professionals and } \\
\text { patient safety. }\end{array}$ & Integrative review & $\begin{array}{l}\text { The working hours and excessive workload are two failures of the format } \\
\text { that have proven to decrease patient safety and the well-being of healthcare } \\
\text { professionals around the world. }\end{array}$ \\
\hline
\end{tabular}


The limitations of the analyzed studies highlighted the type of approach, namely the cross-sectional approach, as a result to be interpreted with caution, because it was a single and temporalcut that can present a response rate of a single specific reality.

Regarding the conclusions of the studies, were emphasized the consequences of how stress may interfere in patient safety, as shown in Chart 2.

The analyzed studies also mentioned possible solutions to address the consequences of stress and Burnout Syndrome in nursing professionals, and incentives to patient safety in the hospital setting, as demonstrated in figure 2 .

The gathering of these actions wasidentifiedin three main pillars: 1) improvements in the working environment, such as greater support to working conditions; 2) management aspects, such as support for organizational behavior aimed at patient safety; and 3) aspects of professionals, such as encouraging teamwork, better professional qualification, coping strategies and better communication.

Chart 2 - Main conclusions presented by the analyzed studies on the patient safety-stress-Burnout Syndrome interface

\begin{tabular}{|c|c|}
\hline Study title & Conclusion of the study \\
\hline $\begin{array}{l}\text { Emotional exhaustion and workarounds in acute care: } \\
\text { cross sectional tests of a theoretical framework }\end{array}$ & $\begin{array}{l}\text { Burnout Syndrome is not simply an individual problem, as it influences the work } \\
\text { environment as a whole because of its relation with the attitudes of professionals. }\end{array}$ \\
\hline $\begin{array}{l}\text { Does clinical incident seriousness and receipt of work- } \\
\text { based support influence mood experienced by nurses } \\
\text { at work? A behavioral diary study }\end{array}$ & $\begin{array}{l}\text { Fatigue and stress can result in complex effects in the workplace that reflect on } \\
\text { poor quality patient care. }\end{array}$ \\
\hline $\begin{array}{l}\text { The impact of the work environment of nurses on patient } \\
\text { safety outcomes: a multi-level modelling approach }\end{array}$ & $\begin{array}{l}\text { Burnout Syndrome provides evidence on the impact on nurses' work and the } \\
\text { organization of their units in the hospital environment. }\end{array}$ \\
\hline $\begin{array}{l}\text { Nursing unit teams matter: impact of unit-level nurse } \\
\text { practice environment, nurse work characteristics, and } \\
\text { burnout on nurse reported job outcomes, and quality of } \\
\text { care, and patient adverse events - a cross sectional survey }\end{array}$ & $\begin{array}{l}\text { Importance of the relationship between workers' feelings of exhaustion, which } \\
\text { are unfavorable to practice. }\end{array}$ \\
\hline $\begin{array}{l}\text { Safety organizing, emotional exhaustion, and turnover } \\
\text { in Hospital Nursing Units }\end{array}$ & $\begin{array}{l}\text { Adverse events were associated with higher levels of emotional exhaustion in } \\
\text { the investigated units. }\end{array}$ \\
\hline $\begin{array}{l}\text { Patient safety, satisfaction and quality of hospital care: } \\
\text { cross sectional surveys of nurses and patients in } 12 \\
\text { countries in Europe and the United States }\end{array}$ & $\begin{array}{l}\text { Association between nursing and safety quality are similar, even though the } \\
\text { levels of each of them vary. }\end{array}$ \\
\hline Negative impacts of shiftwork and long work hours & $\begin{array}{l}\text { The results indicate that professionals' health and patient safety should be } \\
\text { managed simultaneously. }\end{array}$ \\
\hline $\begin{array}{l}\text { Emotional exhaustion and work load predict clinician- } \\
\text { rated and objective patient safety }\end{array}$ & To assist patient safety despite the high workload. \\
\hline $\begin{array}{l}\text { Patient safety and job-related stress: A focus group } \\
\text { study }\end{array}$ & $\begin{array}{l}\text { The demanding work environment coupled with minimal control and social } \\
\text { support from peers result in increased stress with effect on patient safety. }\end{array}$ \\
\hline $\begin{array}{l}\text { Healthcare provider working conditions and well-being: } \\
\text { sharing international lessons to improve patient safety }\end{array}$ & Better working conditions influence patient safety. \\
\hline
\end{tabular}

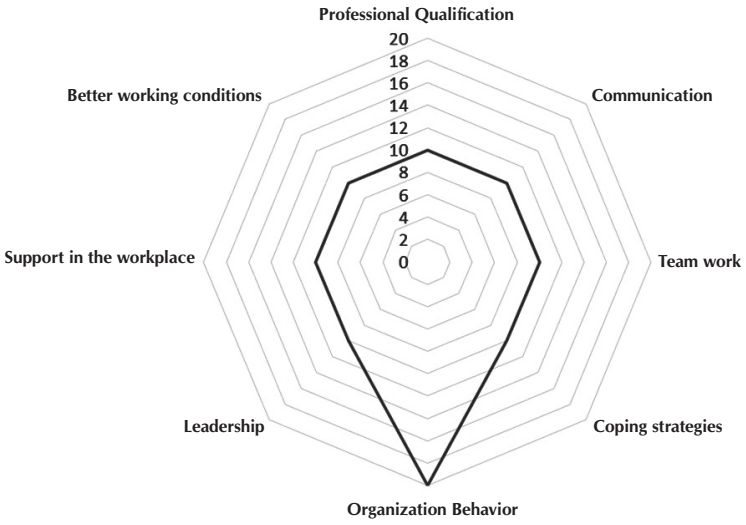

Figure 2 - Factors/strategies of improvements for the patient safety-stress-Burnout Syndrome interface

\section{DISCUSSION}

Regarding the characterization of articles of this review, most publications were original studies published between years 2007 and 2016.

This may be related to the publication of the following reports: 'To Erris Human: Building a Safer Health System' (1999) by the Institute of Medicine (IOM); and 'The Danish Adverse Event Study' (2000) in Denmark, which reinforced studies on the subject of patient safety in health institutions ${ }^{(11)}$.

In addition, the fact that most analyzed publications were from European countries reveals the immense concern with patient safety in these places. This may be associated with great mobilization and requests from the World Health Organization (WHO) to assist in the control of adverse events in health care.

Regarding the environment where the analyzed studies were performed, the hospital was present in all of them. In addition, 
this place of professional practice is associated to the causal link between the health and illness process of its workers ${ }^{(12)}$.

The hospital has characteristics that impact significantly on the daily lives of its workers, since it is an institution articulating complex aspects distributed in a hierarchical structure with multiple technology, and continuous and shiftwork ${ }^{(12)}$.

Thus, psychological and emotional aspects of hospital workers are involved, particularly of nursing professionals ${ }^{(13)}$. They work in a context of accumulation of tasks, work overload, work by shifts and/or at night, deal very closely with the suffering of others and death, create affective bonding with patients and their suffering, and are constantly exposed to risk of contamination.

There is also the fact that the hospital context may have poor management of human resources and supplies to provide care of quality to patients, thereby resulting in poor working conditions for performance of care. Studies mention these aspects as triggers of symptoms of physical and mental exhaustion in professionals working in this type of environment ${ }^{(14)}$.

On this aspect, a study ${ }^{(15)}$ conducted in a North American hospital pointed out that a poorly organized work environment reflects positively on the stress and fatigue of nursing staff members, which can result in unsafe situations for patients.

Hence the conclusion that nursing workers immersed in a stressful daily life start to experience situations that require from them a greatercapacity of adapting to psychological and emotional demands. Consequently, they may experience professional exhaustion and Burnout Syndrome as a response of the body to this stress routine.

A study conducted in a hospital in the Northeast of Brazil found that $68.3 \%$ of the studied nursing professionals presented at least one of the three dimensions of the Burnout Syndrome. Of these, depersonalization and emotional exhaustion stood out, and these are considered the initial stages of the syndrome ${ }^{(16)}$.

Thus, these professionals' fatigue and stress can interact to produce lower quality of patient care and, and increase the frequency of clinical incidents as a consequence ${ }^{(17)}$.

Another aspect that emerged in the results was nursing professionals' excessive workload as a factor for deficient care or of poor quality.

On this aspect, a study ${ }^{(18)}$ conducted in European countries and the United States revealed a rate of patients per nursing staff ranging from 3.3 in Norway to 10.5 in Germany. This fact was related to deficits in the quality of care, neutralization of the nurse before the patient, job dissatisfaction and consequently, a decrease in the quality of hospital care.

This fact was also evident in a study conducted in Brazil on the workload of nursing teammembers. These professionals reported the great volume of activities resulting from the low number of professionals represents a great risk for patient safety ${ }^{(19)}$.

Additionally, it stands out that nursing professionals are immersed in routines of double employment, conciliation with domestic chores and search for better professional qualification. All these aspects result in a daily routine of intensive activities that compromises their time for rest and may reflect on the development of stress and Burnout Syndrome.

On this theme, a study ${ }^{(20)}$ revealed that nurses workingthroughout 12 hours or more in care were three times more likely to make a mistake during assistance compared to those who performed their activities in shifts of 8.5 hours per day. Furthermore, in employees working for more than 40 weekly hours, the risk of causing incidents increased by $46 \%$.

This is evidence that prolonged working hours added to the high workload result in professionals' symptoms of fatigue and physical and mental exhaustion, which causes negative consequences to the care provided for patients.

Regarding the aspects listed as improvements to the patient safety-stress-Burnout Syndrome interface, management strategies were highlighted in the analyzedarticles, among which the encouragement of the organization in relation to aspects of patient safety in the work environment.

There is a growing need to foster a safety culture where information about adverse events can be shared without fear of reprisals and, above all, be a source of learning for the professionals involved.

\section{Limitations of the study}

This integrative review was performed in a single time cut. In addition, as the level of evidence of publications was concentrated in level 5, this may restrict the affirmation of the quality of evidence presented. The number of articles on the subject analyzed - only ten studies - may have also limited the analysis.

\section{Contributions to the area of nursing, health or public policy}

The concern with nursing professionals' health is relevant and contemporary, as it addresses a frequent topic in daily care, particularly regarding stressful situations experienced by these workers. Thus, this study allowed an analysis of the main factors that influence the triggering of stress, and how they can lead to health care assistance failures. In addition, the analyzed publications identify possible actions that contribute to reduce situations of stress and Burnout Syndrome in nursing professionals.

\section{CONCLUSION}

This study enabled a better understanding of the relations between patient safety-stress-Burnout Syndrome in the hospital context of nursing professionals.

According to the analyzed studies, the working environment with precarious working conditions, and the excessive workload of nursing professionalswere consideredas contributing factors to the stress and Burnout Syndrome of these workers.

As a reflection of these workers' daily routine, they are more vulnerable to provide unsafe care. In addition, management strategies aimed at patient safety were citedas a method to be encouraged for ensuring improvement in the quality standard of care provided to patients.

Thus, studies on this theme are essential for promoting reflections about the work environment, working conditions and their consequences for nursing professionals and patient safety.

\section{FUNDING}

Conselho Nacional de Desenvolvimento Científico e tecnológico (CNPq). 


\section{REFERENCES}

1. Reis CT, Martins M, Laguardia J. A segurança do paciente como dimensão da qualidade do cuidado de saúde: um olhar sobre a literatura. Ciênc Cuid Saúde [Internet]. 2013 [cited 2016 Apr 10];18(7):2029-36. Available from: http://www.scielosp.org/pdf/csc/ v18n7/18.pdf

2. Duarte SCM, Stipp MAC, Silva MM, Oliveira FT. Eventos adversos e segurança na assistência de enfermagem. Rev Brasileira de Enferm [Internet]. 2015 [cited 2016 Apr 10];68(1):144-54. Available from: http://www.scielo.br/pdf/reben/v68n1/0034-7167-reben-68-01-0144.pdf

3. Andolhe R. Segurança do paciente em unidades de terapia intensiva: estresse, coping e burnout da equipe de enfermagem e ocorrência de eventos adversos e incidentes. 2013[Tese]. São Paulo: Escola de Enfermagem da Universidade de São Paulo; 2013.

4. Monrouxe LV, Rees EC, Dennis I, Wells SE. Professionalism dilemmas, moral distress and the healthcare student: insights from two online UK-wide questionnaire studies. BMJ Open [Internet]. 2015 [cited 2016 Apr 10];5(5):e007518. Available from: http:// bmjopen.bmj.com/content/5/5/e007518.full.pdf + html

5. Magalhães AMM, Dall 'Agnol CM, Marck PB. Nursing workload and patient safety - a mixed method study with an ecological restorative approach. Rev Latino-Am Enfermagem [Internet]. 2013 [cited 2016 Apr 10];21(esp):9 telas. Available from: http://www. scielo.br/pdf/rlae/v21nspe/19.pdf

6. Goulart LL, Aoki RN, Vegian CFL, Guirardello EB. Carga de trabalho de enfermagem em uma unidade de terapia intensiva de trauma. Rev Eletrôn Enferm [Internet]. 2014 [cited 2016 Apr 10];16(2):346-51. Available from: https://www.fen.ufg.br/fen revista/ v16/n2/pdf/v16n2a10.pdf

7. Zwaan L, Bruijne M, Wagner C, Thijs A, Smits M Vander WG, et.al. Patient record review of the incidence, consequences and causes of diagnostic adverse events. Arch Intern Med[Internet]. 2010[cited 2016 Apr 10];170(12):1015-21. Available from: https:// www.ncbi.nlm.nih.gov/pubmed/20585065

8. Daud-Gallotti RM, Costa SF, Guimarães T, Padilha KG, Inoue EN, Vasconcelos TN et. al. Nursing workload as a risk for healthcare associated infections in ICU: a prospective study. PLOS One [Internet]. 2012 [cited 2016 Apr 10];7(12):e52342. Available from: http://journals.plos.org/plosone/article/file?id = 10.1371/journal. pone.0052342\&type = printable

9. Neill D. Nursing workload and the changing health care environment: a review of the literature. Admin Iss J Educ Pract Res[Internet]. 2010 [cited 2016 Apr 10];1(2):133-43. Available From: http://www.swosu.edu/academics/aij/2011/v1i2-docs/neill.pdf

10. Gonçalves HA. Manual de metodologia da pesquisa científica. São Paulo: Avercamp; 2010.

11. Brasil. Ministério da Saúde. Boletim Informativo sobre a Segurança do Paciente e Qualidade Assistencial em Serviços de Saúde. v.1 n. 1 - Jan-jul 2011. Brasília: GGTES/Anvisa, 2011.

12. Serranheira F, Uva AS, Sousa P. Ergonomia hospitalar e segurança do doente: mais convergências que divergências. Rev Port Saúde Pública [Internet]. 2010[cited 2016 Apr 10];10(n. esp.):58-73. Available from: http://www.cdi.ensp.unl.pt/docbweb/multimedia/rpsp2010-t\%20seg\%20doente/7-ergonomia \%20hospitalar\%20e\%20seguran \%C3\%A7a\%20do\%20doente.pdf

13. Mera MJF, Gaspar RV, Garcia IZ, Sánchez SV, Melero EA, González AS, et al. Síndrome de Burnout em distintas Unidades de Cuidados Intensivos. Enferm Intens [Internet]. 2009 [cited 2016 Apr 10];20(4):131-40. Available from: http://www.elsevier.es/ es-revista-enfermeria-intensiva-142-articulo-sindrome-burnout-distintas-unidades-cuidados-S1130239909732213

14. Monteiro C, Avelar AFM, Pedreira MLG. Interrupções de atividades de enfermeiros e a segurança do paciente: revisão integrativa da literatura. Rev Latino-Am Enfermagem [Internet]. 2015 [cited 2016 Apr 13];23(1):169-79. Available from: http://www.scielo.br/ pdf/rlae/v23n1/pt_0104-1169-rlae-23-01-00169.pdf

15. Raffaerty AM, Clarke SP, Coles J, Ball J, James P, McKee M, et al. Outcomes of variation in hospital nurse staffing in English hospitals: cross-sectional analysis of survey data and discharge records. Int J Nurs Stud [Internet]. 2007 [cited 2016 Apr 13];44(2):17582. Available from: http://www.scielo.br/pdf/rlae/v23n1/pt_0104-1169-rlae-23-01-00169.pdf

16. Galindo RH, Feliciano KVO, Lima RAS, Souza AI. Síndrome de Burnout entre enfermeiros de um hospital geral da cidade do Recife. Rev Esc Enferm USP [Internet]. 2012 [cited 2016 Apr 13];46(2):420-7. Available from: http://www.scielo.br/pdf/reeusp/ v46n2/a21v46n2.pdf

17. Jones MC, Jonhston DW. Does clinical incidente seriousness and receipt of work-based support influence mood experienced by nurses at work? a behavioural diary study. Int J Nurs Stud [Internet]. 2012[cited 2016 Apr 13];(49):978-87. Available from: http:// www.journalofnursingstudies.com/article/S0020-7489(12)00059-4/fulltext

18. Aiken LH, et.al. Patient safety, satisfaction and quality of hospital care: cross sectional surverys of nurses and patients in 12 countries in Europe and the United States. BMJ [Internet]. 2012 [cited 2016 Apr 13];344:e17170 Available from: http://www.bmj.com/ content/bmj/344/bmj.e1717.full.pdf

19. Silva LCP, Juliani CMCM. A interferência da jornada de trabalho na qualidade do serviço: contribuição à gestão de pessoas. RAS [Internet]. 2012 [cited 2016 Apr 13];13(54):12-18. Available from: http://www.cqh.org.br/portal/pag/doc.php?p_ndoc =267

20. Caruso CC. Negative impacts of shiftwork and long work hours. Rehab Nurs [Internet]. 2014[cited 2016 Apr 13];39(1):16-25. Available from: https://www.ncbi.nlm.nih.gov/pubmed/23780784 